\title{
Pengaruh Profitabilitas dan Ukuran Perusahaan Pada Nilai Perusahaan Dengan Good Corporate Governance Sebagai Variabel Pemoderasi
}

\author{
I Putu Putra Wasista ${ }^{1}$ \\ Fakultas Ekonomi dan Bisnis \\ Universitas Udayana, Indonesia. \\ Email: putrawasista@gmail.com
}

\author{
I Nyoman Wijana Asmara Putra ${ }^{2}$ \\ Fakultas Ekonomi dan Bisnis \\ Universitas Udayana, Indonesia.
}

\begin{abstract}
ABSTRAK
Profitabilitas dan ukuran perusahaan menjadi dua dari banyak faktor yang mempengaruhi nilai perusahaan. Penerapapan Good Corporate Governance (GCG) sangat penting sehingga dapat mempengaruhi hubungan antara profitabilitas dan ukuran perusahaan terhadap nilai perusahaan. Penelitian ini dilakukan pada 31 perusahaan manufaktur dengan tahun amatan 5 tahun yaitu 2013 hingga 2017 maka jumlah sampel amatan adalah sebanyak 155 sampel. Didapatkannya 155 sampel amatan yaitu melalui metode pemilihan sampel purposive sampling. MRA atau Moderated Regression Analysis merupakan teknik analisis data yang digunakan dalam penelitian ini. Hasil analisis data yang didapatkan adalah terdapat pengaruh positif antara hubungan profitabilitas dan ukuran perusahaan pada nilai perusahaan serta ditemukan bahwa GCG merupakan variabel pemoderasi yang memperkuat pengaruh profitabilitas dan ukuran perusahaan pada nilai perusahaan.
\end{abstract}

Kata Kunci : Profitabilitas; Ukuran Perusahaan; Good Corporate Governance; Nilai Perusahaan.

\section{The Effect of Profitability and Company Size on Firm Value with Good Corporate Governance as a Moderating Variable}

\begin{abstract}
Profitability and company size are two of the many factors that influence a company's value. Implementation of Good Corporate Governance (GCG) is very important so that it can affect the relationship between profitability and company size on firm value. This research was conducted on 31 manufacturing companies with a 5-year observation period, namely 2013 to 2017, then the total sample of observations was 155 samples. Obtained 155 observational samples through the purposive sampling method. MRA or Moderated Regression Analysis is a data analysis technique used in this study. The results of data analysis obtained are that there is a positive influence between the relationship of profitability and firm size on firm value and found that GCG is a moderating variable that reinforces the effect of profitability and firm size on firm value.
\end{abstract}

Keywords: Profitability; Company Size; Good Corporate Governance; The Value of The Company.

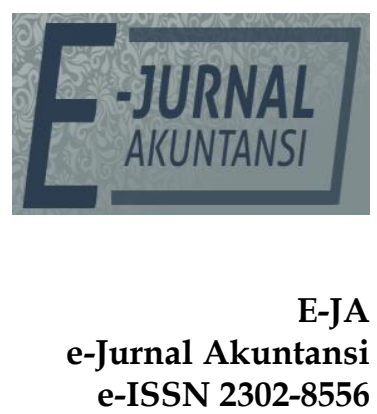

Vol. 29 No. 3

Denpasar, Desember 2019 Hal. 928-942

Artikel masuk: 20 Juni 2019

Tanggal diterima: 28 Agustus 2019 


\section{PENDAHULUAN}

Perusahaan ketika didirikan tentu memiliki misi yang ingin dicapai dimana salah satunya adalah diharapakan perusahaan yang didirikan memiliki nilai perusahaan yang baik. Nilai perusahaan sangat berdampak pada perusahaan yang sudah go public. Nilai perusahaan dianggap sangat penting karena nilai perusahaan dapat mempengaruhi minat investor dalam berinvestasi (Pramana \& Mustanda, 2016). Profitabilitas merupakan kemampuan perusahaan dalam memperoleh keuntungan (laba) atau ukuran efektivitas dalam pengelolaan manajemen perusahaan (Wiagustini, 2010:76). Penelitian ini profitabilitas diproksikan dengan Return On Asset (ROA). Terdapat inkonsistensi dari penelitian sebelumnya mengenai hubungan ROA pada nilai perusahaan. Hasil yang menyatakan bahwa terdapat hubungan antara ROA pada nilai perusahaan ditemukkan oleh penelitian-penelitian sebelumnya yang dilakukan oleh Rizqia \& Sumiati (2013), Korompis \& Wirajaya (2017), Pratama \& Wirawati (2016), dan Gamayuni (2015). Hasil yang menyatakan bahwa tidak terdapat hubungan antara ROA pada nilai perusahaan ditemukkan oleh penelitian-penelitian sebelumnya yang dilakukan oleh Munawaroh (2014), Yastini \& Mertha (2015) dan Herawati (2013).

Selain profitabilitas, terdapat faktor lain yang dapat mempengaruhi nilai perusahaan. Ukuran perusahaan dapat mempengaruhi nilai perusahaan. Perusahaan dengan skala besar memiliki kesempaatan yang lebih besar dalam mendapatkan pendanaan baik dari internal maupun eksternal (Chi, 2005).

Hasil yang menyatakan bahwa terdapat hubungan yang positif antara ukuran perusahaan pada nilai perusahaan ditemukkan oleh penelitian-penelitian sebelumnya yang dilakukan oleh Hidayah (2014), Martini dkk. (2014), Rasyid et al. (2015), serta Pratama \& Wiksuana (2016). Hasil yang menyatakan bahwa tidak terdapat hubungan antara ukuran perusahaan pada nilai perusahaan ditemukkan oleh penelitian-penelitian sebelumnya yang dilakukan oleh Suroto (2016), Prastuti \& Sudiartha (2016) serta Hardian \& Asyik (2016).

Prinsip GCG terkait dengan kepentingan para pemegang saham, perlakuan yang sama terhadap para pemegang saham, peran semua pihak yang berkepentingan (stakeholders), transparansi dan kejelasan. Daily \& Dalton (1994) menyatakan bahwa tata kelola perusahaan yang didasarkan pada teori keagenan adalah Good Corporate Governance (Krenn, 2015).

Diantara empat proksi Good Corporate Governance yang akan digunakan sebagai variabel pemoderasi di penelitian ini adalah proksi yang memiliki skor tertinggi dalam kemampuan menjelaskan hubungan atau korelasi dengan Profitabilitas, Ukuran Perusahaan dan Nilai Perusahaan. Proksi terbaik ini ditentukan terlebih dahulu dengan menggunakan teknik analisis faktor.

Gambar 1 mengenai grafik indeks harga saham perusahaan manufaktur selama tahun 2013 hingga 2015 memberikan gambaran mengenai upaya perusahaan dalam mempertahankan nilai perusahaan yang baik. Adanya peningkatan pada indeks harga saham selama 5 tahun amatan memberikan tanda adanya usaha dari manajemen perusahaan dalam memberikan bukti kinerja yang baik agar membentuk minat investor untuk berinvestasi di perusahaannya. Semakin banyaknya investor yang ingin berinvestasi pada suatu perusahaan akan mempengaruhi nilai perusahaan tersebut. Nilai perusahaan 
cenderung mengalami peningkatan dengan banyaknya investor yang berminat untuk menanamkan modalnya pada perusahaan tersebut.

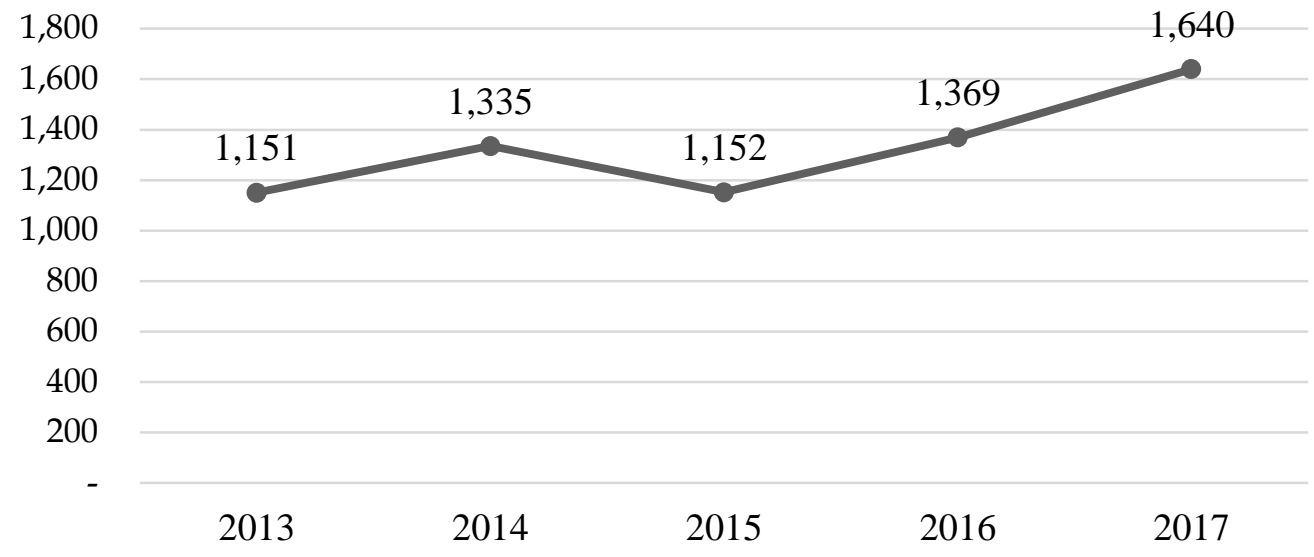

Gambar 1. Grafik Indeks Harga Saham Perusahaan Manufaktur Tahun 20132017

Sumber : www.idx.co.id, 2019

Teori keagenan menjelaskan mengenai hubungan antara principal dengan agent. Hubungan ini didasarkan atas kontrak antara kedua pihak dimana principal memberikan wewenang kepada agent Jensen \& Meckling (1976).

Nilai perusahaaan merupakan harga yang bersedia dibayar oleh calon pembeli apabila perusahaan tersebut dijual (Lu et al., 2010). Apabila perusahaan menawarkan saham ke publik maka nilai perusahaan akan tercermin dari harga saham. Harga saham dapat mencerminkan nilai suatu perusahaan (Wijaya \& Sedana, 2015). Berbagai kebijakan diambil oleh manajemen dalam upaya meningkatkan nilai perusahaan melalui peningkatan kemakmuran pemilik dan pemegang saham tercermin pada harga saham (Brigham \& Houston, 2010). Penelitian ini menggunakan nilai Tobin's $Q$ untuk mengukur nilai perusahaan.

Pada rasio profitabilitas ditunjukkan bagimana upaya perusahaan untuk mendapatkan laba. Berkaitan dengan nilai suatu perusahaan yang dicerminkan dengan harga saham, maka profitabilitas akan lebih tepat diukur dengan menggunakan Return on Asset (ROA). ROA merupakan rasio yang membandingkan antara laba bersih setelah pajak dengan total aset. Jika calon investor ingin melalukan invstasi dalam perusahaan dengan melihat harga saham suatu perusahaan, maka total aset akan lebih mencerminkan harga saham dari pada modal sendiri karena secara umum aktivitas keuangan itu lebih banyak ditentukan oleh total aset perusahaan.

Ukuran perusahaan (firm size) adalah besar kecilnya perusahaan yang dilihat dari besarnya nilai ekuitas, nilai penjualan atau nilai total aktiva (Riyanto, 2010:343). Pengukuran penelitian ini terhadap ukuran perusahaan mengacu pada penelitian sebelumnya Hidayah (2014), serta Pratama \& Wiksuana (2016) yang menyatakan ukuran perusahaan diukur melalui total asset yang diproksikan dengan nilai logaritma natural dari total aset perusahaan.

Menurut Lestari \& Wirawati (2016) tata kelola dalam perusahaan merupakan sebuah sistem internal yang meliputi adanya kebijakan, proses, dan orang-orang yang melayani kebutuhan pemegang saham dan pemangku 
kepentingan lainnya dengan mengarahkan dan mengendalikan kegiatan manajemen melalui praktek bisnis yang baik, objektivitas, dan integritas. Good Corporate Governance dalam proksi mekanisme terdiri dari Kepemilikan Manajerial, Kepemilikan Institusional, Komite Audit dan Dewan Komisaris.

Kepemilikan manajerial adalah besarnya saham yang dimiliki manajemen dari total saham yang beredar (Kusumaningtyas, 2015). Kepemilikan Institusional adalah besarnya jumlah saham yang dimiliki institusi dari total saham beredar (Sinarmayarani \& Suwitho, 2016). Komite audit adalah kelompok orang-orang terpilih yang diberi tugas yang secara khusus diberikan pada kelompok tersebut. Komite audit haruslah independen. Tugas utama dari Dewan komisaris independen yaitu bertanggung jawab atas kualitas informasi yang diasilkan oleh perusahaan. Tugas ini menjadikan dewan komisaris independen memiliki peran penting dalam menjalankan mekanisme pengawasan terhadap kegiatan operasional perusahaan. Semakin kompeten dewan komisaris independen akan memberikan citra positif perusahaan dimata masyarakat. Publik akan memberikan respon yang baik terhadap perusahaan karena merasa perusahaan dengan proporsi dewan komisaris.

Beberapa penelitian sebelumnya yang dilakukan oleh Chen \& Chen (2011), Pratama \& Wirawati (2016), Gamayuni (2015), Hermuningsih (2017), Rasyid et al. (2015), serta Wijaya \& Sedana (2015) memperoleh hasil bahwa profitabilitas berpengaruh positif dan signifikan terhadap nilai perusahaan. Hasil tersebut memiliki arti bahwa setiap peningkatan nilai pada profitabilitas akan mengakibatkan peningkatan pula pada nilai perusahaan.

$\mathrm{H}_{1}$ : Profitabilitas berpengaruh positif terhadap nilai perusahaan.

Beberapa penelitian sebelumnya yang dilakukan oleh Hidayah (2014), Martini et al. (2014), Rasyid et al. (2015) serta Pratama \& Wiksuana (2016) memperoleh hasil bahwa ukuran perusahaan berpengaruh positif dan signifikan terhadap nilai perusahaan.

$\mathrm{H}_{2}$ : Ukuran Perusahaan berpengaruh positif terhadap nilai perusahaan.

GCG dapat mengurangi potensi konflik keagenan antara prinsipal dan agen. GCG dinilai mampu mendorong terbentuknya pola kerja manajemen yang bersih, transparan, dan profesional sehingga dapat meningkatkan profitabilitas perusahaan itu sendiri, maka dapat menjadi daya tarik bagi investor sehingga akan meningkatkan nilai perusahaan. Hasil penelitian yang dilakukan oleh Mawati dkk. (2017), Maulana (2016), dan Imron dkk. (2013) bahwa GCG memperkuat pengaruh profitabilitas pada nilai perusahaan. Berdasarkan pernyataan tersebut dapat ditarik hipotesis sebagai berikut.

$\mathrm{H}_{3}$ : Good corporate governance memperkuat pengaruh profitabilitas pada nilai perusahaan.

Hasil penelitian Lestari \& Wirawati (2018) menemukan bahwa GCG memperkuat hubungan ukuran perusahaan terhadap nilai perusahaan. Penelitian lainnya yang dilakukan oleh Pratama \& Wiksuana (2016) serta Kusumayanti \& Astika (2016) menyatakan bahwa ukuran perusahaan berpengaruh pada nilai perusahaan, sedangkan hasil penelitian Retno \& Priantinah (2012) menunjukkan bahwa GCG berpengaruh pada nilai perusahaan. Berdasarkan pernyataan tersebut dapat ditarik hipotesis sebagai berikut. 
$\mathrm{H}_{4}$ : Good corporate governance memperkuat pengaruh ukuran perusahaan pada nilai perusahaan

\section{METODE PENELITIAN}

Lokasi penelitian ini dilakukan pada perusahaan manufaktur yang terdaftar di Bursa Efek Indonesia yang dimana data tersebut diperoleh dari laporan keuangan perusahaan manufaktur tahun 2013-2017 melalui alamat website www.idx.co.id. Objek dalam penelitian ini adalah nilai perusahaan pada perusahaan manufaktur yang terdaftar di Bursa Efek Indonesia tahun 2013-2017.

Dalam Penelitian ini variabel yang digunakan terdiri dari variabel independen dan variabel dependen. Variabel Independen merupakan variabel bebas yang mempengaruhi variabel lainnya, adapun variabel bebas yang digunakan dalam penelitian ini adalah profitabilitas, dan ukuran perusahaan. Variabel Dependen merupakan variabel terikat yang dipengaruhi oleh variabel bebas lainnya, dan dalam penelitian ini variabel yang dimaksud adalah nilai perusahaan. Variabel pemoderasi yang digunakan adalah pengungkapan good corporate governance.

Profitabilitas (X1). Rasio profitabilitas adalah sekelompok rasio yang menunjukan kombinasi dari pengaruh likuiditas, manajemen aset dan hutang pada hasil operasi (Brigham \& Houston, 2010;146). Proksi dari profitabilitas uang digunakan adalah ROA. Rasio ini diukur dengan rumus dari skala pengukuran yang digunakan (Brigham \& Houston, 2010:148) :

Return on Asset $(\mathrm{ROA})=\frac{\text { Laba Bersih }}{\text { Total Asset }} \times 100 \%$.

Ukuran Perusahaan (X2). Proksi dari ukuran perusahaan yang digunakan pada penelitian ini adalah logaritma natural of total asset. Dirumuskan sebagai berikut (Nurhayati, 2013) :

Ukuran Perusahaan $($ size $)=$ Ln Of Total Asset.

Nilai Perusahaan (Y). Proksi dari nilai perusahaan adalah Tobin's Q. Tobin's $Q$ adalah salah satu rasio yang dinilai bisa memberikan informasi paling baik, karena rasio ini bisa menjelaskan berbagai fenomena dalam kegiatan perusahaan (Dianawati \& Fuadati, 2016). Rumus Tobin's $Q$ adalah sebagai berikut (Suartawan \& Yasa, 2016):

$$
\mathrm{Q}=\frac{M V E+D e b t}{T A}
$$

Keterangan :

$\mathrm{Q} \quad=$ Nilai Perusahaan

MVE = Nilai pasar ekuitas (jumlah saham beredar $\mathrm{x}$ closing price)

Debt = Nilai buku hutang

TA $=$ Nilai buku total aset

Pada penelitian ini Good Corporate Governance menjadi variabel pemoderasi yang diproksikan oleh proksi yang terbaik dari empat unsur didalamnya. Proksi terbaik didapatkan dengan cara analisis faktor keempat unsur GCG. Sebelum dilakukan analisis faktor masing-masing unsur GCG diukur terlebih dahulu dengan masing-masing formulasinya, uraian pengukuran keempat unsur dalam GCG serta formulasinya adalah sebagai berikut:

Kepemilikan manajerial adalah jumlah presentase saham perusahaan yang di pegang oleh pihak manajerial atau internal perusahaan (Wulandari \& 
Budiartha, 2014). Pada penelitian ini proksi kepemilikan manajerial akan dihitung presentase jumlah saham yang dimiliki oleh pihak manajerial dengan formulasi sebagai berikut:

$$
\mathrm{KM}=\frac{\text { Jumlah saham yang dimiliki pihak manajemen }}{\text { jumlah saham perusahaan yang beredar }} \times 100 \%
$$

Menurut Dananjaya \& Ardiana (2016) kepemilikan institusional yaitu jumlah presentase saham serta hak suara yang dimiliki oleh institusi. Pada proksi kepemilikan institusional diukur dari jumlah presentase saham yang dimiliki oleh institusi. Formulasi untuk perhitungan kepemilikan institusional untuk sebuah perusahaan adalah sebagi berikut:

$$
\mathrm{KI}=\frac{\text { Jumlah } \text { saham yang dimiliki pihak institusi }}{\text { Jumlah saham perusahaan yng beredar }} \times 100 \%
$$

Komite audit adalah kelompok orang-orang terpilih yang diberi tugas yang secara khusus diberikan pada kelompok tersebut. Komite audit haruslah independen (Komite Nasional Kebijakan Governance, 2006). Berdasarkan penelitian yang dilakukan oleh Haryani \& Wiratmaja (2014) penelitian ini menggunakan proksi komite audit yang diukur dengan menghitung presentase dari perbandingan jumlah komite audit dengan jumlah total dewan komisaris yang ada dalam perusahaan yang diteliti. Perhitungannya dapat diformulasikan sebagai berikut:

$$
\mathrm{KA}=\frac{\text { Jumlah Anggota Komite Audit }}{\text { Jumlah Anggota Dewan Komisaris }} \times 100 \%
$$

Tugas utama dari Dewan komisaris independen yaitu bertanggung jawab atas kualitas informasi yang diasilkan oleh perusahaan. Tugas ini menjadikan dewan komisaris independen memiliki peran penting dalam menjalankan mekanisme pengawasan terhadap kegiatan operasional perusahaan. Proporsi dihitung dengan menggunakan rumus:

$$
\text { DKI }=\frac{\text { Jumlah anggota dewan komisaris independen }}{\text { Jumlah total dewan komisaris }} \times 100 \% \text {. }
$$

Jenis data digunakan dalam penelitian ini adalah kuantitatif. Data kuantitatif adalah data penelitian berupa angka-angka dan analisis menggunakan statistik (Sugiyono, 2017:10). Data Kuantitatif yang digunakan dalam penelitian ini adalah laporan keuangan tahunan, serta harga saham perusahaan manufaktur periode 2013-2017.

Data sekunder dalam penelitian ini berupa laporan keuangan perusahaan manufaktur tahun 2013-2017 yang diunduh dari website www.idx.co.id, dan harga saham harian dengan mengakses www.finance.yahoo.com. Populasi dalam penelitian ini yaitu seluruh perusahaan manufaktur yang terdaftar di Bursa Efek Indonesia (BEI) dari tahun 2013-2017.

Kriteria yang digunakan untuk memilih sampel adalah perusahaan manufaktur yang terdaftar pada paeriode 2013-2017 yang mempublikasikan laporan keuangan auditan dengan menggunakan tahun buku yang beralhir pada 31 Desember serta tidak melaporkan kerugian selama periode pengamatan dan Perusahaan manufaktur yang terdaftar di BEI tahun 2013 sampai dengan 2017, memiliki data lengkap mengenai variabel yang diteliti pada laporan keuangan tahunan perusahaan yang diterbitkan dari tahun 2013 sampai dengan 2017. 
Tabel 1. Hasil Perhitungan Sampel

\begin{tabular}{ll}
\hline Kriteria & Jumlah \\
\hline $\begin{array}{l}\text { Perusahaan manufaktur yang terdaftar di Bursa Efek Indonesia (BEI) } \\
\text { selama periode 2013-2017 }\end{array}$ & 129 \\
$\begin{array}{l}\text { Perusahaan yang tidak mempublikasikan laporan keuangan secara } \\
\text { berturut-turut periode 2013-2017 }\end{array}$ & \\
$\begin{array}{l}\text { Perusahaan manufaktur yang mengalami kerugian periode 2013-2017 } \\
\text { Tidak memiliki data lengkap mengenai variabel yang diteliti dalam }\end{array}$ & $(32)$ \\
$\begin{array}{l}\text { laporan keuangan periode 2013-2017 } \\
\text { Jumlah Sampel }\end{array}$ & 31 \\
\hline
\end{tabular}

Sumber: Data Penelitian, 2019

Metode pengumpulan data dalam penelitian ini dilakukan dengan cara melakukan studi dokumentasi. Adapun dokumen di dalam penelitian ini adalah laporan keuangan perusahaan manufaktur yang terdaftar di Bursa Efek Indonesia (BEI) yang diperoleh dari website www.idx.co.id.

\section{HASIL DAN PEMBAAHASAN}

Penelitian ini dilakukan pada 31 perusahaan manufaktur dengan tahun amatan 5 tahun yaitu 2013 hingga 2017 maka jumlah sampel amatan adalah sebanyak 155 sampel. Hasil pemilihan sampel penelitian disajikan pada Tabel 2 berikut:

Tabel 2. Proses dan Hasil Seleksi Sampel berdasarkan Kriteria

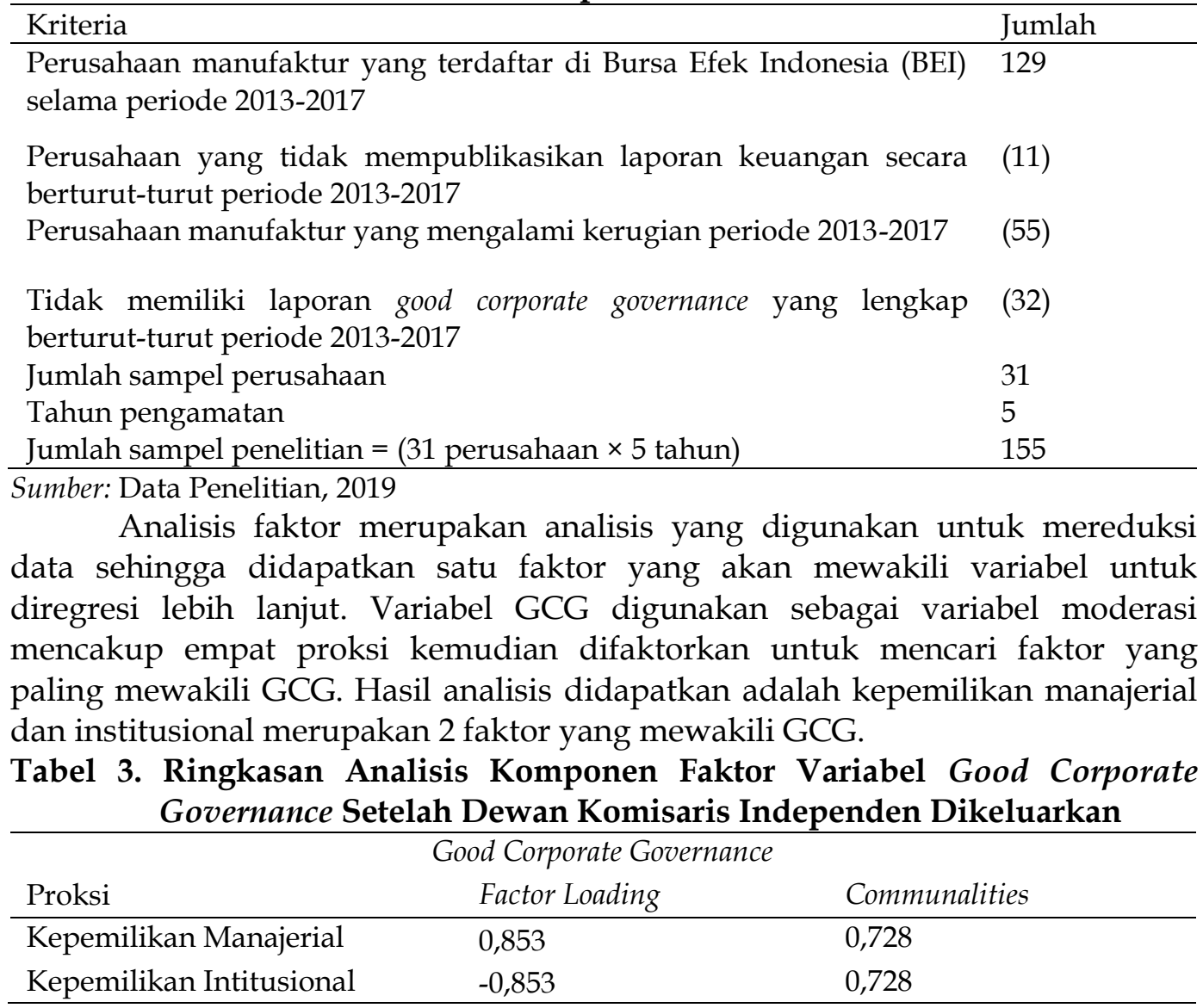

Sumber: Data Penelitian, 2019 
Nilai communalities dari kedua mekanisme tersebut lebih besar dari 0,50, hal ini menunjukkan bahwa kedua mekanisme tersebut dapat digunakan untuk mewakili faktor good corporate governance.

Tabel 4. Hasil Analisis Statistik Deskriptif

\begin{tabular}{llllll}
\hline & $\mathrm{N}$ & Minimum & Maximum & Mean & Std. Deviation \\
\hline ROA & 155 & 0,00 & 0,26 & 0,074 & 0,053 \\
Size & 155 & 25,62 & 33,32 & 28,420 & 1,827 \\
Tobins_Q & 155 & 0,30 & 9,70 & 1,712 & 1,375 \\
GCG & 155 & $-1,46$ & 3,19 & 0,000 & 1,000 \\
Valid N (listwise) & 155 & & & &
\end{tabular}

Sumber: Data Penelitian, 2019

Pada hasil analisis statistik deskriptif didapatkan hasil bahwa mean masing masing variabel mendekati nilai minimumnya masing masing. $X_{1}$ dengan nilai minimum dan maksimum 0,00 dan 0,26 . Nilai mean dari $X_{1}$ adalah 0,074 dimana mendekati nilai minimum dari $X_{1}$. Hasil ini memiliki arti bahwa rata-rata perusahaan manufaktur memiliki ROA yang rendah. $X_{2}$ dengan nilai minimum dan maksimum 25,62 dan 33,32. Nilai mean dari $X_{2}$ adalah 28,420 dimana mendekati nilai minimum dari $\mathrm{X}_{2}$. Hasil ini memiliki arti bahwa rata-rata perusahaan manufaktur memiliki ukuran perusahaan yang rendah. $\mathrm{Y}$ dengan nilai minimum dan maksimum 0,30 dan 9,70. Nilai mean dari $\mathrm{Y}$ adalah 1,712 dimana mendekati nilai minimum dari Y. Hasil ini memiliki arti bahwa rata-rata perusahaan manufaktur memiliki nilai perusahaan yang rendah. $Z$ dengan nilai minimum dan maksimum $-1,46$ dan 3,19. Nilai mean dari $Z$ adalah 0,000 dimana mendekati nilai minimum dari $\mathrm{Z}$. Hasil ini memiliki arti bahwa rata-rata perusahaan manufaktur memiliki penerapan GCG yang rendah.

Tabel 5. Hasil Uji Normalitas

\begin{tabular}{ll}
\hline & Unstandardized Residual \\
\hline $\mathrm{N}$ & 155 \\
Kolmogorov-Smirnov $\mathrm{Z}$ & 1,307 \\
Asymp.Sig.(2-tailed) & 0,066 \\
\hline
\end{tabular}

Sumber: Data Penelitian, 2019

Setelah dilakukan uji normalitas hasil yang didapatkan adalah bahwa model persamaan regresi berdistribusi normal. Hasil ini merupakan kesimpulan dari tabel 11 dimana dapat dilihat nilai Asymp. Sig. (2-tailed) yang melebihi 0,05 yaitu sebesar 0,066 .

Tabel 6. Hasil Uji Multikolinearitas

\begin{tabular}{llll}
\hline Variabel & Tolerance & VIF & Keterangan \\
\hline ROA & 0,860 & 1,163 & Bebas multikol \\
Size & 0,767 & 1,304 & Bebas multikol \\
GCG & 0,277 & 3,616 & Bebas multikol \\
Interaksi X1.Z & 0,950 & 1,053 & Bebas multikol \\
Interaksi X2.Z & 0,250 & 3,998 & Bebas multikol \\
\hline
\end{tabular}

Sumber: Data Penelitian, 2019

Hasil dari uji multikolinearitas menunjukkan bahwa model yang digunakan terbebas dari masalah multikolinearitas. Hal ini didasari dari hasil pengujian yang menunjukkan bahwa nilai tolerance dan nilai VIF masing masing 
variabel berhasil memenuhi syarat yaitu nilai tolerance yang melebihi dari 0,1 dan nilai VIF yang kurang dari 10.

Tabel 7. Hasil Uji Autokorelasi

\begin{tabular}{llllll}
\hline Model & $\mathrm{R}$ & R Square & $\begin{array}{l}\text { Adjusted } \\
\text { Square }\end{array}$ & $\begin{array}{c}R \\
\text { Std. Error of the } \\
\text { Estimate }\end{array}$ & Durbin-Watson \\
\hline 1 & $0,781^{\text {a }}$ & 0,610 & 0,597 & 0,87265 & 1,908 \\
\hline
\end{tabular}

Sumber: Data Penelitian, 2019

Berdasarkan hasil uji autokorelasi didapatkan nilai Durbin-Watson sebesar 1,914. Kriteria agar tidak terdapat autokorelasi adalah nilai DW harus melebihi dari nilai du dimana nilai du untuk penelitian ini adalah 1,79058. Nilai du diperoleh dengan melihat jumlah sampel, nilai signifikansi, dan juml ah variabel independen yang digunakan. Selain melebihi nilai du, nilai DW juga harus kurang dari nilai (4-du) yaitu 2,20942. Hasil dari perbandingan ketiga nilai ini adalah 1,79058 < 1,914 < 2,20942 maka disimpulkan bahwa tidak terdapat autokorelasi.

Tabel 8. Hasil Uji Heteroskedastisitas

\begin{tabular}{|c|c|c|c|c|c|}
\hline & \multicolumn{2}{|c|}{ Unstandardized Coefficients } & \multirow{2}{*}{$\begin{array}{l}\text { Standardized } \\
\text { Coefficients } \\
\text { Beta } \\
\end{array}$} & \multirow[b]{2}{*}{$\mathrm{t}$} & \multirow[b]{2}{*}{ Sig. } \\
\hline & $\mathrm{B}$ & Std. Error & & & \\
\hline (Constant) & $-9,156$ & 11,652 & & $-0,786$ & 0,433 \\
\hline ROA & 13,950 & 13,421 & 0,091 & 1,039 & 0,300 \\
\hline Size & 0,332 & 0,414 & 0,074 & 0,802 & 0,424 \\
\hline GCG & 0,095 & 0,973 & 0,015 & 0,098 & 0,922 \\
\hline X1.Z & 0,354 & 0,833 & 0,035 & 0,424 & 0,672 \\
\hline $\mathrm{X} 2 . \mathrm{Z}$ & 0,038 & 0,047 & 0,130 & 0,803 & 0,423 \\
\hline
\end{tabular}

Sumber: Data Penelitian, 2019

Berdasarkan hasil uji heteroskedaastisitas dapat disimpulkan bahwa tidak terdapat gejala heteroskedastisitas. Hal ini dilihat dari nilai Sig. masing-masing variabel yang melebihi 0,05 .

Tabel 9. Hasil Analisis Regresi Moderasi

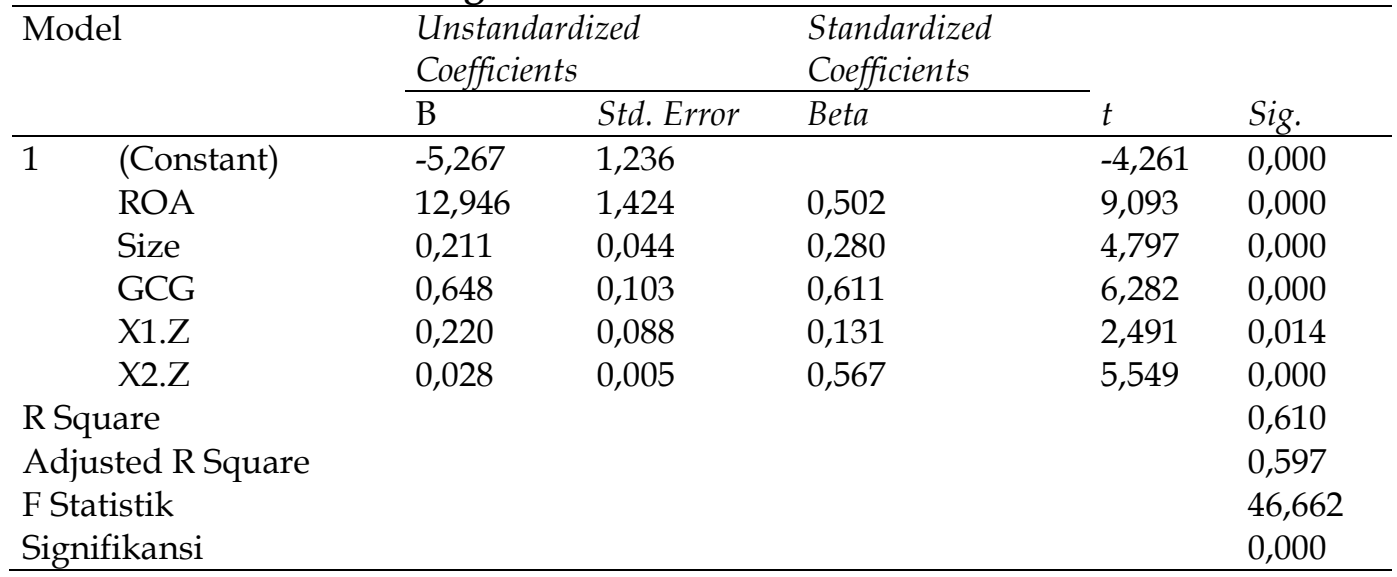

Sumber: Data Penelitian, 2019

$Y=-5,267+12,946 X_{1}+0,211 X_{2}+0,648 Z+0,220 X_{1} * Z+0,028 X_{2} * Z+\varepsilon$

Berdasarkan hasil uji regresi diatas, dapat diketahui bahwa nilai konstanta sebesar -5,267 memiliki arti apabila variabel independen $X_{1} X_{2}, Z, X 1 . Z$, dan X2.Z bernilai konstan, maka variabel $Y$ akan mengalami penurunan sebesar 5,267. Nilai $\beta_{1}$ dari $X_{1}$ sebesar 12,946 . Nilai ini memiliki arti jika $X_{1}$ mengalami kenaikan 
sebesar satu satuan, hal ini berdampak pada peningkatan nilai $Y$ sebesar 12,946. Variabel independen lainnya diasumsikan konstan. Nilai $\beta_{2}$ dari $X_{2}$ sebesar 0,211. Nilai ini memiliki arti jika $X_{2}$ mengalami kenaikan sebesar satu satuan, hal ini berdampak pada peningkatan nilai $Y$ sebesar 0,211. Variabel independen lainnya diasumsikan konstan. Nilai $\beta_{3}$ dari $Z$ sebesar 0,648 . Nilai ini memiliki arti jika $Z$ mengalami kenaikan sebesar satu satuan, hal ini berdampak pada peningkatan nilai $Y$ sebesar 0,648. Variabel independen lainnya diasumsikan konstan. Nilai $\beta_{4}$ dari $X_{1} Z$ sebesar 0,220 . Nilai ini memiliki arti jika $X_{1} Z$ mengalami kenaikan sebesar satu satuan, hal ini berdampak pada peningkatan nilai $Y$ sebesar 0,220. Variabel independen lainnya diasumsikan konstan. Nilai $\beta_{5}$ dari $\mathrm{X}_{2} Z$ sebesar 0,028 . Nilai ini memiliki arti jika $X_{2} Z$ mengalami kenaikan sebesar satu satuan, hal ini berdampak pada peningkatan nilai $Y$ sebesar 0,028 . Variabel independen lainnya diasumsikan konstan.

Pada Tabel 9 didapatkan hasil nilai $\mathrm{R}^{2}$ sebesar 0,597. Variabel independen yang digunakan dalam penelitian ini dapat menjelaskan variasi dari nilai perusahaan sebesaar $59,7 \%$. Sisanya sebanyak $40,3 \%$ dijelaskan oleh faktor lain diluar variabel yang digunakan dalam penelitian ini.

\section{Tabel 10. Uji Anova}

\begin{tabular}{lllllll}
\hline Model & & Sum of Squares & $d f$ & Mean Square & F & Sig. \\
\hline 1 & Regression & 177,672 & 5 & 35,534 & 46,662 & $0,000^{\mathrm{a}}$ \\
& Residual & 113,467 & 149 & 0,762 & & \\
& Total & 291,140 & 154 & & & \\
& & &
\end{tabular}

Sumber: Data Penelitian, 2019

Didapatkan hasil yaitu nilai Sig. yaitu 0,000. Dengan nilai Sig. 0,000 maka dapat disimpulkan bahwa model yang digunakan adalah layak. Kriteria yang harus dipenuhi agar model dianggap layak adalah nilai Sig. P value 0,000 yang kurang dari 0,05.

Hasil dari pengujian hipotesis pertama yaitu didapatkan nilai signifikansi yang kurang dari 0,05 yaitu nilai signifikansi 0,000. Nilai ini menunjukkan bahwa $\mathrm{H}_{1}$ diterima. Selain nilai signifikansi, dilihat nilai koefisien regresi yang positif berarti pengaruh yang dihasilkan adalah positif. disimpulkan bahwa terdapat pengaruh positif dari hubungan $\mathrm{X}_{1}$ pada $\mathrm{Y}$. Hasil ini didukung oleh teori sinyal dimana peningkatan pada nilai perusahaan cenderung terjadi pada perusahaan yang melaporkan informasi keuangannya. Profitabilitas mengandung informasi mengenai pengelolaan keuangan dari perusahaan dan upaya perusahaan dalam menghasilkan laba. Ketika perusahaan menginformasikan nilai profitabilitas perusahaan dalam keadaan baik, investor cenderung memiliki respon positif terhadap informasi tersebut. Respon positif ini dapat meningkatkan minat investor dalam berinvestasi pada perusahaan sehingga kemudian berpengaruh pada peningkatan nilai perusahaan. Hasil penelitian yang serupa ditemukan oleh penelitian sebelumnya yang dilakukan oleh Chen \& Chen (2011), Pratama \& Wirawati (2016), Gamayuni (2015), Hermuningsih (2017), Rasyid et al. (2015), serta Wijaya \& Sedana (2015).

Hasil dari pengujian hipotesis kedua yaitu didapatkan nilai signifikansi yang kurang dari 0,05 yaitu nilai signifikansi 0,000. Nilai ini menunjukkan bahwa $\mathrm{H}_{2}$ diterima. Selain nilai signifikansi, dilihat nilai koefisien regresi yang positif berarti pengaruh yang dihasilkan adalah positif. disimpulkan bahwa terdapat 
pengaruh positif dari hubungan $\mathrm{X}_{2}$ pada $\mathrm{Y}$. Hasil ini didukung oleh teori sinyal yang menyatakan bahwa ukuran suatu perusahaan dapat mempengaruhi nilai suatu perusahaan. Investor dalam menentukan perusahaan yang akan ditanamkan modalnya tentunya menginginkan perusahaan tersebut memiliki keadaaan keuangaan yang stabil. Investor cenderung memiliki persepsi bahwa semakin besar ukuran perusahaan maka keadaan keuangannya tergolong stabil. Hal ini didasari dari mudahnya perusahaan dengan ukuran yang besar mendapatkan pendanaan baik internal maupun eksternal. Hasil penelitian serupa ditemukan dalam penelitian sebelumnya yang dilakukan oleh Hidayah (2014), Martini et al. (2014), Rasyid et al. (2015) serta Pratama \& Wiksuana (2016).

Hasil dari pengujian hipotesis ketiga yaitu didapatkan nilai signifikansi yang kurang dari 0,05 yaitu nilai signifikansi 0,014. Nilai ini menunjukkan bahwa $\mathrm{H}_{3}$ diterima. Selain nilai signifikansi, dilihat nilai koefisien regresi yang positif berarti pengaruh yang dihasilkan adalah positif. disimpulkan bahwa pengaruh profitabilitas pada nilai perusahaan dimoderasi oleh GCG. GCG merupakan variabel moderasi yang memperkuat pengaruh profitabilitas pada nilai perusahaan. Hasil penelitian serupa ditemukan dalam penelitian sebelumnya yang dilakukan oleh Mawati dkk. (2017), Maulana (2016), dan Imron dkk. (2013).

Hasil dari pengujian hipotesis keempat yaitu didapatkan nilai signifikansi yang kurang dari 0,05 yaitu nilai signifikansi 0,000. Nilai ini menunjukkan bahwa $\mathrm{H}_{4}$ diterima. Selain nilai signifikansi, dilihat nilai koefisien regresi yang positif berarti pengaruh yang dihasilkan adalah positif. disimpulkan bahwa pengaruh ukuran perusahaan pada nilai perusahaan dimoderasi oleh GCG. GCG merupakan variabel moderasi yang memperkuat pengaruh ukuran perusahaan pada nilai perusahaan. Hasil penelitian serupa ditemukan dalam penelitian sebelumnya yang dilakukan oleh Lestari \& Wirawati (2018).

\section{SIMPULAN}

Berdasarkan hasil penelitian yang diperoleh melalui analisi data serta pembahasan seperti yang telah diuraikan pada bab sebelumnya, maka dapat ditarik kesimpulan sebagai berikut, profitabilitas sebagai $X_{1}$ memiliki pengaruh yang positif pada $\mathrm{Y}$ yaitu nilai perusahaan. Didukung oleh teori sinyal, hasil temuan ini memiliki arti bahwa perusahaan yang memiliki ROA yang baik cenderung akan direspon positif oleh investor yang kemudian berdampak pada peningkatan nilai perusahaan. Ukuran perusahaan sebagai $X_{2}$ memiliki pengaruh yang psoitif pada nilai $Y$. Pernyataan dari teori sinyal mengenai besarnya ukuran perusahaan dapat mempengaruhi nilai perusahaan mendukung hasil dari penelitian ini. GCG merupakan variabel moderasi yang memperkuat pengaruh profitabilitas pada nilai perusahaan dan pengaruh ukuran perusahaan pada nilai perusahaan.

\section{REFERENSI}

Agustina, S. (2013). Pengaruh Profitabilitas dan Pengungkapan Corporate Social Responsibility Terhadap Nilai Perusahaan (Studi Empiris pada Perusahaan Manufaktur yang Terdaftar di Bursa Efek Indonesia). Jurnal, 1, 1-23.

Analisa, Y. (2011). Pengaruh DER , CSR, Profitabilitas dan Kebijakan Dividen terhadap Nilai Perusahaan (Studi pada Perusahaan Manufaktur yang 
Terdaftar di BEI Indonesia Tahun 2006-2008). Jurnal Ekonomi.

Brigham, E. F., \& Houston, J. F. (2010). Manajemen Keuangan Edisi Kedelapan. Jakarta: Erlangga. https:// doi.org/10.1016/0377-841X(78)90069-4

Chen, L. J., \& Chen, S. Y. (2011). The Influence of Profitability on Firm Value With Capital Structure as The Mediator And Firm Size and Industry as Moderators. Investment Management and Financial Innovations, 3(8), 121-129.

Chi, J. (2005). Understanding the endogeneity between firm value and shareholder rights. Financial Management, 34(4), 65-76. https://doi.org/10.1111/j.1755-053X.2005.tb00118.x

Daily, C. M., \& Dalton, D. R. (1994). Bankruptcy and Corporate Governance: The Impact of Board Composition and Structure. The Academy of Management Journal, 37(6), 1603-1617. https:// doi.org/https://doi.org/10.5465/256801

Dananjaya, D. G. Y., \& Ardiana, P. A. (2016). Proporsi Dewan Komisaris Independen Sebagai Pemoderasi Pengaruh Kepemilikan Institusional Pada Manajemen Laba. E-Jurnal Akuntansi Universitas Udayana, 15(2), 87-91.

Dewi, N. K. D. P., \& Mertha, I. M. (2018). Pengungkapan Tanggung Jawab Sosial Memoderasi Pengaruh Profitabilitas dan Ukuran Perusahaan pada Nilai Perusahaan. E-Jurnal Akuntansi Universitas Udayana, 22(3), 2148-2176.

Gamayuni, R. R. (2015). The Effect Of Intangible Asset, Financial Performance and Financial Policies on The Firm Value. International Journal of Economics and Financial Issues, 4(1), 202-212.

Ghozali, I. (2016). Aplikasi Analisis Multivariate dengan Program IBM SPSS 21 :Update PLS Regresi. Semarang: Badan Penerbit Universitas Diponegoro. https://doi.org/10.2307/1579941

Gill, A., \& Mathur, N. (2011). Factors that Influence Financial Leverage of Canadian Firms. Journal of Applied Finance E Banking, 1(2), 19-37. https://doi.org/10.5539/ijef.v4n3p33

Hall, B. H. (1986). the Relationship Between Firm Size and Firm Growth in the U.S. Manufacturing Center. Nber Working Paper Series, (June), 1-57. Retrieved from https:/ / www.nber.org/papers/w1965.pdf

Hardian, A. P., \& Asyik, N. F. (2016). Kinerja Keuangan dan Ukuran Perusahaan Terhadap Nilai Perusahaan, CSR Sebagai Variabel Moderasi. Jurnal Ilmu $\mathcal{E}$ Riset Akuntansi, STESIA, 5(9), 1-16.

Hartono, J. (2016). Teori Portofolio dan Analisis Investasi. Yogyakarta: BPFE. https://doi.org/ISSN 0101-4234

Haryani, J., \& Wiratmaja, i D. N. (2014). Pengaruh Ukuran Perusahaan, Komite Audit, Penerapan International Financial Reporting Standards dan Kepemilikan Publik Pada Audit Delay. E-Jurnal Akuntansi Universitas Udayana, 6(1), 63-78.

Herawati, T. (2013). Pengaruh Kebijakan Dividen, Kebijakan Hutang dan Profitabilitas Terhadap Nilai Perusahaan. E-Journal UNP, 2(2), 1-18.

Hermuningsih, S. (2013). Pengaruh Profitabilitas, Growth Opportunity, Struktur Modal Terhadap Nilai Perusahaan Pada Perusahaan Publik Di Indonesia. Buletin Ekonomi Moneter Dan Perbankan, 16(2), 127-148. https://doi.org/10.21098/bemp.v16i2.27

Imron, G. S., Hidayat, R., \& Alliy, S. (2013). Pengaruh Kinerja Keuangan dan Ukuran Perusahaan Terhadap Nilai Perusahaan dengan Corporate Sosial 
Responsibility dan Good Corporate Governance Sebagai Variabel Moderasi. Potensio, 18(2), 82-93.

Jensen, M. C., \& Meckling, W. H. (1976). Theory of the Firm: Managerial Behaviour, Agency, Costs and Ownership. Journal of Financial Economics, 3, 305-360. https:/ / doi.org/http:/ /dx.doi.org/10.1016/0304-405X(76)90026-X

Khika Indira Putri Hermawan Korompis, \& Wirajaya, I. G. A. (2017). Pengaruh Kinerja Keuangan Pada Nilai Perusahaan Dengan Good Corporate Governance Sebagai Variabel Pemoderasi. E-Jurnal Akuntansi Universitas Udayana, 21(1), 1-28.

Komite Nasional Kebijakan Governance. (2006). Pedoman Umum Good Corporate Governance Indonesia. Komite Nasional Kebijakan Governance. https://doi.org/10.1021/ic035198d

Krenn, M. (2015). Understanding Decoupling in Response to Corporate Governance Reform Pressures: The Case of Codes of Good Corporate Governance. Journal of Financial Regulation and Compliance. https://doi.org/10.1108/JFRC-04-2014-0019

Kusumayanti, N. K. R., \& Astika, I. B. P. (2016). Corporate Social Responsibility Sebagai Pemediasi Pengaruh Ukuran Perusahaan, Profitabilitas Dan Leverage Pada Nilai Perusahaan. E-Jurnal Akuntansi Universitas Udayana, 15(1), 549-583.

Lestari, D. S. N. D., \& Wirawati, N. G. P. (2018). Pengaruh Ukuran Perusahaan dan Pengungkapan CSR Terhadap Nilai Perusahaan dengan GCG Sebagai Variabel Pemoderasi. E-Jurnal Akuntansi Universitas Udayana, 23(2), 13861414.

Lestari, S. D., \& Wirawati, N. G. P. (2016). Good Corporate Governance Sebagai Pemoderasi Pengaruh Asimetri Informasi Pada Manajemen Laba. E-Jurnal Akuntansi Universitas Udayana, 16(1), 156-182.

Lu, Y. H., Tsai, C. F., \& Yen, D. C. (2010). Discovering important factors of intangible firm value by association rules. International Journal of Digital Accounting Research, 10, 55-85. https://doi.org/10.4192/1577-8517-v10_3

Machfoedz, M. (1994). Financial Ratio Analysis and the Prediction of Earning Changes in Indonesia. Kelola.

Martini, N. N. G., Moeljadi, Djumahir, \& Djazuli, A. (2014). Factors Affecting Firms Value of Indonesia Public Manufacturing Firms. International Journal of Business and Management Invention, 3(2), 35-44.

Maulana, A. (2016). Pengaruh kinerja keuangan terhadap nilai perusahaan dengan mekanisme good corporate governance sebagai variabel moderasi. JOM Fekom, 3(1), 993-1005.

Mawati, E. R., Hardiningsih, P., \& Srimindarti, C. (2017). Corporate governance memoderasi earning management dan profitabilitas terhadap nilai perusahaan. Prosiding Seminar Nasional Multi Disiplin Ilmu $\mathcal{E}$ Call For Papers Unisbank, 3, 519-528.

Morris, R. D. (1987). Signalling, Agency Theory and Accounting Policy Choice. Accounting and Business Research, 18(69), 47-56. https://doi.org/10.1080/00014788.1987.9729347

Nila, L., \& Suryanawa, I. K. (2018). Pengaruh Profitabilitas dan Ukuran Perusahaan Terhadap Nilai Perusahaan dengan Pengungkapan Corporate 
Social Responsibility Sebagai Pemoderasi. E-Journal Akuntansi Universitas Udayana, 23(3), 2145-2174.

Nurhayati, M. (2013). Profitabilitas, Likuiditas dan Ukuran Perusahaan Pengaruhnya Terhadap Kebijakan Dividen dan Nilai Perusahaan Sektor Non Jasa. Jurnal Keuangan Dan Bisnis, 2(5), 144-153.

Permatasari, L. W., \& Gayatri. (2016). Profitabilitas Sebagai Pemoderasi Pengaruh Good Corporate Governance Pada Nilai Perusahaan. E-Jurnal Akuntansi Universitas Udayana, 14(3), 2307-2335.

Pramana, I. G. N. A. D., \& Mustanda, I. K. (2016). Pengaruh Profitabilitas dan Size Terhadap Nilai Perusahaan Dengan CSR Sebagai Variabel Pemoderasi. E-Jurnal Manajemen Unud, 5(1), 561-594.

Pratama, I. G. B. A., \& Wiksuana, I. G. B. (2016). Pengaruh Ukuran Perusahan dan Leverage terhadap Nilai Perusahaan dengan Profitabilitas sebagai Variabel Mediasi. E-Jurnal Manajemen Unud, 5(2), 1338-1367.

Pratama, I. G. G. W., \& Wirawati, N. G. P. (2016). Pengaruh Struktur Modal dan Profitabilitas Terhadap Nilai Perusahaan Dengan Kepemilikan Manajerial Sebagai Pemoderasi. E-Jurnal Akuntansi Universitas Udayana, 15(3), 17961825.

Pratiwi, N. P. D., \& Mertha, M. (2017). Pengaruh Kebijakan Hutang dan Profitabilitas Pada Nilai Perusahaan Dengan Kebijakan Dividen Sebagai Variabel Pemoderasi. E-Jurnal Akuntansi Universitas Udayana, 20(2), 14461475. https://doi.org/10.1038/srep44329

Rasyid, A., Mahfudnurnajamuddin, Mas'ud, M., \& Su'un, M. (2015). Effect of Ownership Structure, Company size and Profitability on Dividend Policy and Manufacturing Company's value in Indonesia Stock Exchange. Basic and Applied Sciences, 9(20), 618-624.

Retno, R. D., \& Priantinah, D. (2012). Pengaruh Good Corporate Governance dan Pengungkapan Corporate Social Responsibility Terhadap Nilai Perusahaan (Studi Empiris Pada Perusahaan yang Terdaftar di BEI Periode 2007-2009). Nominal: Barometer Riset Akuntansi Dan Manajemen, 1(2), 84-103. https://doi.org/998-3068-1-pb.pdf

Riyanto, B. (2010). Dasar-Dasar Pembelanjaan Perusahaan. Yogyakarta: BPFE.

Rizqia, D. A., \& Sumiati, S. A. (2013). Effect of Managerial Ownership, Financial Leverage, Profitability, Firm Size, and Investment Opportunity on Dividend Policy and Firm Value. Research Journal of Finance and Accounting, 4(11), 2222-2847.

Sinarmayarani, A., \& Suwitho. (2016). Pengaruh Kepemilikan Institusional danProfitabilitas terhadap Nilai Perusahaan melalui Kebijakan Dividen. Jurnal Ilmu Dan Riset Manajemen Sekolah Tinggi Ilmu Ekonomi Indonesia (STIESIA) Surabaya, 5(5), 1-18.

Suartawan, I. G. N. P. A., \& Yasa, G. W. (2016). Pengaruh Investment Opportunity Set dan Free Cash Flow Pada Kebijakan Dividen dan Nilai Perusahaan. Jurnal Ilmiah Akuntansi Dan Bisnis, 11(2), 63-74. https://doi.org/10.24843/jiab.2016.v11.i02.p01

Sugiyono. (2017). Metode Penelitian Pendidikan Pendekatan Kuantitatif, Kualitatif, dan RED. Bandung: Alfabeta.

Sukamulja, S. (2004). Good Corporate Governance di Sektor Keuangan: Dampak 
Good Corporate Governance Terhadap Kinerja Keuangan. BENEFIT, 8(1), 125.

Suroto. (2016). Determinan Nilai Perusahaan. Jurnal Universitas 17 Agustus 1945 Semarang, 5(1), 38-54.

Wiagustini, N. L. P. (2010). Dasar-Dasar Manajemen Keuangan. Denpasar: Udayana University Press.

Wijaya, B. I., \& Sedana, I. B. P. S. (2015). Pengaruh Profitabilitas Terhadap Nilai Perusahaan (Kebijakan Dividen dan Kesempatan Investasi Sebagai Variabel Mediasi). E-Jurnal Manajemen Unud, 4(12), 4477-4500. 